\title{
PERSOALAN DESAIN KEBIJAKAN CARRY OVER DALAM PEMBENTUKAN UNDANG-UNDANG DI INDONESIA DITINJAU DARI ASPEK POLITIK HUKUM
}

\author{
Muldan Halim P, Ali Abdurahman, Mei Susanto \\ Universitas Padjadjaran | Jl. Raya Bandung-Sumedang Km. 2 I Jatinangor, Kab. \\ Sumedang, Jawa Barat | muldan I600 I@mail.unpad.ac.id. \\ Universitas Padjadjaran | Jl. Raya Bandung-Sumedang Km. 2I Jatinangor, Kab. \\ Sumedang, Jawa Barat |abdurahman.5832@gmail.com. \\ Universitas Padjadjaran | Jl. Raya Bandung-Sumedang Km. 2 I Jatinangor, Kab. \\ Sumedang, Jawa Barat |m.susanto@unpad.ac.id.
}

Abstract: As a policy that bridges the legislation program between periods, carry over in Law No. 15 of 2019 is projected to be able to prevent waste and ineffectiveness of resources as well as provide certainty for promulgation in the legislation making. However, in practice, the carry over policy has not had a significant impact by only being able to pass one of the four bills with carry over status in the National Legislation Program (Prolegnas) 2020. That is related to the design of the carry over policy which contain several problems. This paper attempts to analyze the extent of the carry over policy can be realized in the legal politics of sustainable legislation making in Indonesia. The method used is juridical-sociological research with qualitative-descriptive data analysis. The result of this analysis show that the current design of carry over policy needs to be evaluated and adjusted with the established permanent and temporary legal policy, to make it capable to realizing savings and effectiveness of resources as well as providing certainty in the effort to realize the sustainability on legislation making in Indonesia.

Keywords: Carry Over, Legal Policy, Legislation Making, Policy Design, Sustainable Legislation Making

Abstrak: Sebagai kebijakan yang menjembatani program legislasi antarperiode, carry over dalam Undang-Undang (UU) Nomor I 5 Tahun 2019 diproyeksikan mampu mencegah pemborosan dan inefektifitas sumber daya serta memberikan kepastian pengundangan dalam proses pembentukan UU. Namun, dalam praktiknya, kebijakan carry over tidak 
Muldan Halim P, et.al.

memberikan dampak yang signifikan dengan hanya mampu meloloskan satu dari empat rancangan undang-undang (RUU) yang berstatus carry over dalam Program Legislasi Nasional (Prolegnas) prioritas 2020. Hal ini berkaitan dengan desain kebijakan carry overyang mengandung beberapa persoalan. Tulisan ini berusaha menganalisis sejauh mana kebijakan carry over dapat diwujudkan dalam politik hukum pembentukan UU yang berkelanjutan di Indonesia. Metode penelitian yang digunakan adalah yuridis-sosiologis dengan teknik analisis data kualitatif-deskriptif. Hasil analisis menunjukan, desain kebijakan carry over yang ada saat ini perlu dievaluasi serta disesuaikan dengan politik hukum permanen dan temporer yang telah ditetapkan, agar mampu mewujudkan penghematan dan efektifikasi sumber daya serta memberikan kepastian dalam upaya mewujudkan pembentukan UU yang berkelanjutan di Indonesia.

Kata kunci: Carry Over, Desain Kebijakan, Pembentukan UU, Pembentukan UU Berkelanjutan, Politik Hukum

\section{Pendahuluan}

Agenda memperkuat pembentukan undang-undang (UU) yang berkelanjutan dalam UU Nomor 15 Tahun 2019 tentang Perubahan atas Undang-Undang Nomor 12 Tahun 2011 tentang Pembentukan Peraturan Perundang-Undangan (UU P3 Perubahan) dilekatkan pada sebuah ketentuan yang disebut dengan ketentuan carry over atau ketentuan luncuran ${ }^{1}$ atau operan ${ }^{2}$. Sebagai sebuah ketentuan yang dirumuskan dalam UU, ketentuan carry over diharapkan menjadi kebijakan terobosan dalam proses pembentukan UU yang berkelanjutan. Tujuan dari kebijakan ini adalah mengadakan payung hukum pembahasan rancangan undang-undang (RUU) lintas periode ${ }^{3}$ agar setiap RUU yang telah direncanakan, disusun, dan dibahas bersama oleh pembentuk UU (DPR, Presiden, dan/atau DPD), namun belum terselesaikan pada periode tertentu dapat dilanjutkan pada periode selanjutnya.

\footnotetext{
' BPHN, Tiga Dekade Prolegnas Dan Peran BPHN (Jakarta: Departemen Hukum dan Hak Asasi Manusia RI, 2008). Dalam buku ini, istilah "luncuran" digunakan sebagai padanan "carry over".

2 Istilah "operan" digunakan sebagai padanan "carry over" dalam Peraturan DPR Nomor 2 Tahun 2020 Tentang Pembentukan Undang-Undang.

${ }^{3}$ Periode yang dimaksud adalah periode masa jabatan pembentuk undang-undang, khususnya DPR.
} 
Keinginan untuk dapat melanjutkan pembahasan RUU dari suatu periode kepada periode selanjutnya berangkat dari anggapan bahwa, ketiadaan ketentuan yang mengatur mengenai keberlanjutan pembahasan RUU dalam UU Nomor 12 Tahun 2011 tentang Pembentukan Peraturan Perundang-Undangan (UU P3) membuat pembentukan undang-undang di Indonesia bersifat periodik dan tidak mencerminkan suatu perencanaan yang berkelanjutan. ${ }^{4}$ Dengan berakhirnya periode DPR, maka berakhir pula proses pembentukan UU. Penghentian pembahasan ketika pergantian periode ini kendati tidak secara eksplisit diatur dalam UU P3, namun dipraktikan oleh DPR. ${ }^{5}$

Konsekuensi yang timbul adalah proses perencanaan pembentukan UU oleh DPR periode yang baru, akan memulai kembali dari awal (nol). ${ }^{6}$ Hal tersebut dianggap merugikan karena menimbulkan pemborosan, mengingat bahwa RUU yang telah memasuki tahap pembicaraan tingkat I (pembahasan oleh DPR dengan Pemerintah) telah menghabiskan sumberdaya, waktu dan anggaran yang cukup besar, namun pada periode yang baru harus diulang kembali penyusunanya dari awal, karena keterbatasan waktu dalam pembahasan. ${ }^{7}$

Dengan mendasarkan pada UU P3 Perubahan, kebijakan carry over langsung diterapkan pada peralihan periode 2014-2019 dan periode 2019-2024. Karenanya Program Legislasi Nasional (Prolegnas) 2020-20248 dihiasi oleh 4 (empat) RUU ${ }^{9}$ berstatus operan

\footnotetext{
${ }^{4}$ Badan Legislasi DPR RI, Naskah Akademik Rancangan Undang-Undang Republik Indonesia Tentang Perubahan Atas Undang-Undang Nomor 12 Tahun $201 /$ Tentang Pembentukan Perundang-Undangan (lakarta: DPR-RI, 2019).

${ }^{5}$ Badan Legislasi DPR-RI, Evaluasi Prolegnas Tahun 2010-20/4 (Jakarta: DPR-RI, 20I4), 33, http://repositori.dpr.go.id/28/.

${ }^{6} \mathrm{lbid}$.

7 Badan Legislasi DPR-RI, Naskah Akademik..., 3.

8 Sebagaimana disampaikan dalam bahan yang dibagikan dalam kegiatan kunjungan kerja Badan Legislasi DPR RI ke Provinsi Jawa Barat dalam rangka sosialisasi prolegnas RUU tahun 2020-2024 dan prolegnas RUU prioritas tahun 2020 di Auditorium Mochtar Kusumaatmadja Unpad Kampus Dipatiukur pada 30 Januari 2020.

${ }^{9}$ lbid, Keempat RUU tersebut yakni RUU tentang Kitab Undang-Undang Hukum Pidana (RUU KUHP), RUU tentang Perubahan atas Undang-Undang Nomor 12 Tahun 1995 tentang Permasyarakatan (RUU PAS), RUU tentang Perubahan atas Undang-Undang Nomor 4 Tahun
} 
dari periode sebelumnya. Keempat RUU carry over tersebut dimasukkan ke dalam Prolegnas prioritas 2020. Namun demikian. hingga tulisan ini rampung, baru satu RUU carry over yang telah disahkan menjadi UU.10 Selain itu, desain kebijakan carry over sebagaimana tertuang dalam rumusan Pasal 71A UU P3 Perubahan, tidak sesuai dengan politik hukum pembentukan UU yang telah digariskan dalam Undang-Undang Dasar Negara Republik Indonesia (UUD NRI) 1945, sehingga carry over tidak mampu memberikan dampak yang signifikan dalam pembentukan UU di Indonesia. Hal ini menarik dianalisis selain untuk mengevaluasi kebijakan carry over pada tahun pertama penerapannya, namun juga untuk memberikan gambaran sejauh mana carry over dapat diwujudkan dalam politik hukum pembentukan UU yang berkelanjutan pada tahun-tahun berikutnya.

Berangkat dari uraian di atas, maka muncul pertanyaan yang hendak diselidiki dalam tulisan ini dengan rumusan yakni sejauh mana kebijakan carry over dapat diwujudkan dalam politik hukum pembentukan UU yang berkelanjutan di Indonesia?

\section{Metode Penelitian}

Tulisan ini merupakan penelitian deskriptif-analitis, yaitu jenis penelitian yang bekerja dengan mengumpulkan data, fakta serta analisis dari hasil penelitian guna mendukung argumentasi hukum secara sistematis dan terstruktur. ${ }^{11}$ Metode pendekatan yang digunakan adalah yuridis-sosiologis yaitu suatu bentuk kombinasi antara banyak pendekatan yang berada dalam suatu rumpun ilmu-ilmu sosial yang dikombinasikan dengan pendekatan

2009 tentang Pertambangan Mineral dan Batu Bara (RUU Minerba), dan RUU tentang Perubahan atas Undang-Undang Nomor 13 Tahun 1985 tentang Bea Materai.

${ }^{10}$ RUU Minerba

I' B. Arief Sidharta, Meuwissen Tentang Pengembangan Hukum, Ilmu Hukum, Teori Hukum Dan Filsafat Hukum (Bandung: Refika Aditama, 2003), 56-57. 
yang dikenal dalam ilmu hukum seperti asas-asas, doktrin, dan hierarki perundang-undangan. ${ }^{12}$

\section{Pijakan Konsep dan Teori}

Indonesia ialah negara hukum (rechstaat) yang tidak terlepas dari tradisi hukum Eropa Kontinental (civil law). ${ }^{13}$ Karakter sistem hukum tersebut tertanam dalam sistem hukum Indonesia akibat pengaruh sistem hukum kolonial Belanda ${ }^{14}$ yang berlaku selama 350 tahun masa penjajahan ${ }^{15}$. Prinsip utama yang menjadi dasar civil law itu ialah hukum memperoleh kekuatan mengikat, karena diwujudkan dalam peraturan-peraturan yang berbentuk UU dan tersusun secara sistematik di dalam kodifikasi atau kompilasi tertentu. ${ }^{16}$ Kepastian hukum merupakan tujuan hukum, oleh karena itulah yang menjadi sumber hukum utama di dalam sistem civil law -begitu juga di Indonesia- adalah UU.

UU sangat penting karena merupakan penjabaran lebih lanjut dari konstitusi. ${ }^{17}$ Bagaimana UU itu dibentuk dan apa isi dari UU itu ditentukan peraturan perundangan di atasnya yang lebih tinggi yaitu konstitusi. ${ }^{18}$ Menurut Crabbe, the important part of legislation is not only the regulatory aspect but the law-making process itself, aspek terpenting dari peraturan perundang-undangan bukan hanya mengenai pengaturannya melainkan juga proses pembentukannya. ${ }^{19}$ Sementara itu, pembentukan UU yang

\footnotetext{
12 Herlambang P. Wiratraman, "Penelitian Sosio-Legal Dan Konsekuensi Metodologisnya" (Surabaya: Center of Human Right Law Studies (HRLS), Fakultas Hukum Universitas Airlangga, t.t.), I, https:/herlambangperdana.files.wordpress.com/2008/06/penelitian-sosio-legal-dalam-tun.pdf. 13 Mukhlis Taib, Dinamika Perundang-Undangan Di Indonesia (Bandung: Refika Aditama, 20 I7), 22.

14 Ibid., 23.

${ }^{15}$ Mugiyati, Pengkajian Konstitusi (Jakarta: Badan Pembinaan Hukum Nasional, 201 I), 68.

${ }^{16}$ Abdoel Djamali, Pengantar Hukum Indonesia Edisi Revisi (Jakarta: Rajawali Pers, 20 I4), 69.

${ }^{17}$ A. Rosyid Al Atok, Konsep Pembentukan Peraturan Perundang-Undangan (Malang: Setara Press, 20I5), 3.

18 Ibid., 4.

${ }^{19}$ Badan Legislasi DPR-RI, Naskah Akademik..., 17.
} 
berkelanjutan sendiri berarti proses pembentukan tersebut mampu melewati seluruh rangkaian atau tahapan yang mesti dilalui. ${ }^{20}$

Dalam pembuatan peraturan perundang-undangan, termasuk pembentukan UU, tidak dapat dilepaskan dari politik hukum. Studi politik hukum penting digunakan dalam memahami secara inklusif produk hukum melalui pendekatan interdisipliner. ${ }^{21}$ Politik hukum berfungsi: pertama, sebagai alasan mengapa suatu peraturan perundang-undangan dibentuk; kedua, untuk menentukan apa yang hendak diterjemahkan ke dalam kalimat hukum dan menjadi perumusan pasal. ${ }^{22}$ Menurut Soedarto, politik hukum ialah usaha untuk mewujudkan peraturan-peraturan yang baik sesuai dengan keadaan dan situasi pada suatu waktu. ${ }^{23}$ Sementara menurut Teuku Muhammad Radhie, politik hukum merupakan suatu pernyataan kehendak mengenai hukum yang diberlakukan dan hukum yang hendak dibangun. ${ }^{24}$ Bagir Manan mengatakan, politik hukum ada yang bersifat tetap (permanen) dan ada juga yang sementara/temporer (dapat berubah). ${ }^{25}$ Politik hukum dapat digunakan sebagai alat untuk menilai dan mengkritisi apakah suatu hukum yang dibuat telah sesuai atau belum dengan kerangka pikir yang menjadi tujuan negara. ${ }^{26}$

Salah satu ruang lingkup utama politik hukum adalah politik pembentukan hukum. ${ }^{27}$ Dalam upaya pembentukan hukum, wujud politik hukum dapat ditemukan dalam Prolegnas ${ }^{28}$, tepatnya

20 Yuliandri, Asas-Asas Pembentukan Peraturan Perundang-Undangan Yang Baik: Gagasan Pembentukan Undang-Undang Berkelanjutan (Jakarta: PT Raja Grafindo Persada, 2009), 251.

2l Syahriza Alkohir Anggoro, "Politik Hukum: Mencari Sejumlah Penjelasan," Jurnal Cakrawala Hukum Vol. 10, No. I (Juni 2019): 85-86.

${ }^{22}$ Abdul Latif dan Hasbi Ali, Politik Hukum (Jakarta: Sinar Grafika, 2010$), 19$.

${ }^{23}$ Soedarto, Hukum Pidana Dan Perkembangan Masyarakat Kajian Terhadap Hukum Pidana (Bandung: Sinar Baru, 1983), 20.

${ }^{24}$ Imam Syaukani dan A. Ahsin Thohari, Dasar-Dasar Politik Hukum (lakarta: PT Raja Grafindo Persada, 2012), 27.

${ }^{25}$ Bagir Manan, Politik Perundang-Undangan (Cisarua-Bogor: Penataran Dosen FH/STH PTS SeIndonesia, 1993), 2-3.

26 Moh. Mahfud MD, Membangun Politik Hukum Menegakkan Konstitusi (Jakarta: Rajawali Pers, 20I2), 16.

${ }^{27}$ Bagir Manan, Politik Perundang-Undangan..., 4.

${ }_{28}$ Moh. Mahfud MD, Membangun Politik..., 5. 
sebagai politik hukum temporer. ${ }^{29}$ Sebagai bagian politik hukum yang bersifat temporer, maka Prolegnas tidak dapat dilepaskan dari politik hukum yang bersifat permanen sehingga harus dibangun berdasarkan, serta untuk memperkokoh sendi-sendi Pancasila dan UUD NRI 1945. ${ }^{30}$ Oleh karena carry over dirancang untuk masuk ke dalam Prolegnas dan Prolegnas harus dibangun untuk memperkokoh sendi-sendi UUD NRI 1945, maka desain kebijakan carry over tidak dapat dilepaskan dari kedua instrumen tersebut.

\section{Persoalan Desain Kebijakan Carry Over dalam Pembentukan UU di Indonesia}

Diterapkannya kebijakan carry over pada peralihan dari periode 2014-2019 ke periode 2019-2024 menunjukan secara faktual bahwa kebijakan carry over telah mampu diwujud-nyatakan dalam proses pembentukan UU di Indonesia. Melihat respon publik, hadir dan diterapkannya kebijakan carry over sama sekali tidak menimbulkan diskursus dan dinilai positif karena dipandang sangat diperlukan untuk memecah kebuntuan proses legislasi akibat habisnya periode masa jabatan. Menurut Penulis, pandangan ini terutama timbul dari persepsi yang tidak tepat ketika menempatkan carry over dalam konstruksi politik hukum pembentukan UU, yakni menganggap bahwa carry over sebagai arah politik hukum dalam pembentukan UU. ${ }^{31}$ Padahal, carry over lebih tepat dikatakan sebagai bentuk kebijakan, sementara arah kebijakan dibalik carry over itu sendiri adalah terwujudnya pembentukan UU yang berkelanjutan yang dalam pandangan Yuliandri berarti mampu melewati seluruh rangkaian atau tahapan yang mesti dilalui. Dengan kata lain, diterapkannya kebijakan carry

\footnotetext{
29 Mei Susanto, "Penguatan Prolegnas Sebagai Dasar Politik Pembentukan Undang-Undang," dalam Strategi Perampingan Dan Harmonisasi Regulasi Pusat Dan Daerah (Jakarta: Badan Pengkajian MPR-RI, 20I7), 335.

$30 \mathrm{lbid} ., 336$.

${ }^{31}$ Sopiani dan Zainal Mubaroq, "Politik Hukum Pembentukan Peraturan Perundang-Undangan Pasca Perubahan Undang-Undang Nomor 12 Tahun 201 I Tentang Pembentukan Peraturan Perundang-Undangan," Jurnal Legislasi Indonesia Vol. 17, No. 2 (Juni 2020), I5I .
} 
over belum tentu membuat proses pembentukan UU yang berkelanjutan itu terwujud.

Pada praktik, dalam daftar Prolegnas prioritas 2020, terdapat 4 (empat) RUU yang ditetapkan sebagai RUU carry over. Keempat RUU tersebut yakni RUU tentang Kitab Undang-Undang Hukum Pidana (RUU KUHP), RUU tentang Perubahan atas UndangUndang Nomor 12 Tahun 1995 tentang Permasyarakatan (RUU PAS), RUU tentang Perubahan atas Undang-Undang Nomor 4 Tahun 2009 tentang Pertambangan Mineral dan Batu Bara (RUU Minerba), dan RUU tentang Perubahan atas Undang-Undang Nomor 13 Tahun 1985 tentang Bea Materai. ${ }^{32}$ Dari keempat RUU dengan status carry over tersebut, hingga tulisan ini rampung, hanya RUU Minerba yang telah disahkan menjadi UU.

Fakta tersebut menunjukan kebijakan carry over tidak mampu memberikan dampak signifikan terhadap pembentukan UU yang berkelanjutan. Hal ini menurut Penulis berhubungan dengan beberapa persoalan yang berkaitan dengan desain kebijakan carry over itu sendiri. Pasalnya sebagai sebuah kebijakan yang menjembatani antarperiode politik, pengaturan carry over hanya dituangkan ke dalam satu buah pasal. Hal ini menurut Penulis merupakan suatu sikap over simplifikasi yang membuat perwujudan kebijakan carry over pada satu momen menjadi terpasung, namun pada momen yang lain dapat menjadi tidak terkendali dalam upaya mewujudkan proses pembentukan UU yang berkelanjutan di Indonesia. Berikut di bawah ini adalah beberapa persoalan yang dapat penulis jelaskan:

\footnotetext{
32 Sebagaimana disampaikan dalam bahan yang dibagikan dalam kegiatan kunjungan kerja Badan Legislasi DPR RI ke Provinsi Jawa Barat dalam rangka sosialisasi prolegnas RUU tahun 2020-2024 dan prolegnas RUU prioritas tahun 2020 di Auditorium Mochtar Kusumaatmadja Unpad Kampus Dipatiukur pada 30 Januari 2020.
} 


\section{Rumusan yang Tidak Mengikat dan Tidak Memberikan Kepastian}

Ketentuan kebijakan carry over diletakkan pada Pasal 71A UU P3 Perubahan dengan rumusan sebagai berikut:

"Dalam hal pembahasan Rancangan Undang-Undang sebagaimana dimaksud dalam Pasal 65 ayat (1) telah memasuki pembahasan Daftar Inventarisasi Masalah pada periode masa keanggotaan DPR saat itu, hasil pembahasan Rancangan Undang-Undang tersebut disampaikan kepada DPR periode berikutrya dan berdasarkan kesepakatan DPR, Presiden, dan/atau DPD, Rancangan Undang-Undang tersebut dapat dimasukkan kembali ke dalam daftar Prolegnas jangka menengah dan/atau Prolegnas prioritas tahunan"

Rumusan tersebut merupakan desain atas kebijakan carry over. Dari rumusan itu, desain kebijakan carry over dapat diurai menjadi empat poin sebagai berikut:

1) Carry over berada dalam konteks pembahasan RUU yang dilakukan oleh DPR bersama Presiden atau Menteri yang ditugasi;

2) RUU bersangkutan telah memasuki pembahasan Daftar Inventarisasi Masalah (DIM) pada periode masa keanggotaan DPR sebelumnya;

3) Carry over didasarkan pada kesepakatan DPR, Presiden, dan/atau DPD, dan;

4) RUU bersangkutan dapat dimasukkan kembali ke dalam daftar Prolegnas jangka menengah dan/atau Prolegnas prioritas tahunan.

Mengacu kepada desain tersebut, carry over baru dapat dilakukan terhadap suatu RUU yang pembahasannya belum selesai pada periode masa jabatan DPR sebelumnya jika mendapatkan persetujuan berdasarkan kesepakatan DPR, Presiden, dan/atau DPD. 
Kesepakatan menjadi faktor kunci untuk menjalankan kebijakan carry over. Bagaimanapun suatu RUU pada periode sebelumnya telah dibahas hingga memasuki atau bahkan melampaui pembahasan DIM, apabila tidak disepakati oleh DPR, Presiden dan/atau DPD maka RUU tersebut tidak dapat dimasukkan kembali ke dalam daftar Prolegnas jangka menengah dan/atau Prolegnas prioritas tahunan serta tidak dapat dilanjutkan pembahasannya pada periode berikutnya. Dengan desain yang demikian itu, kebijakan carry over belum tentu dapat membuat proses pembahasan RUU pada suatu periode akan berlanjut pada periode berikutnya. Apalagi, pembentukan UU juga melibatkan Presiden yang pergantian jabatannya bersamaan dengan pergantian masa jabatan DPR. Apabila Presiden yang menjabat berganti (berbeda dengan Presiden pada periode sebelumnya) dan membawa visi-misi legislasi yang berbeda dengan Presiden sebelumnya, maka carry over boleh jadi tidak dapat dilakukan, karena tidak disepakati oleh Presiden yang baru tersebut.

Desain yang ada saat ini membuat kebijakan carry over menjadi sebuah kebijakan tanpa kepastian karena disandarkan pada kesepakatan. Hal ini juga dipertegas dengan penggunaan frasa "... dapat dimasukkan ..." yang menandakan bahwa carry over hanya didesain sebagai sebuah pilihan (opsi). Sebagai sebuah pilihan, carry over tidak mampu memunculkan ikatan tanggung jawab keberlanjutan pembahasan sebuah RUU dari satu periode kepada periode berikutnya.

\section{Tidak Sejalan dengan Gagasan}

Desain carry over pada Pasal 71A UU P3 Perubahan tidak sejalan dengan gagasan memperkuat proses pembentukan UU yang berkelanjutan sebagaimana yang diniatkan pada mulanya. Terkait gagasan awal diaturnya 
carry over sendiri, dapat ditemukan dalam naskah akademis RUU tentang perubahan atas UU No. 12 Tahun 2011 yang menjadi dasar terbentuknya UU P3 Perubahan. Hal ini karena naskah akademis memuat gagasan-gagasan pengaturan dan materi muatan $\mathrm{UU}^{33}$ serta sebagai pemberi arah kepada perancang UU untuk dapat menentukan apa yang akan diatur dan diterjemahkan ke dalam kalimat hukum. ${ }^{34}$

Dalam naskah akademis RUU tentang perubahan atas UU No. 12 Tahun 2011, ${ }^{35}$ didapati beberapa poin yang mencerminkan kehendak otentik diadakannya ketentuan carry over yakni:

1) Guna penghematan dan efektifitas sumberdaya, waktu dan anggaran dengan maksud:

a. Agar sumberdaya, waktu, dan anggaran tidak terbuang sia-sia; ${ }^{36}$

b. Agar tidak terjadi pemborosan akibat proses pembahasan yang diulang kembali dari nol. ${ }^{37}$

2) Memastikan pembahasan suatu RUU berlangsung secara berkelanjutan hingga RUU bersangkutan dapat diundangkan. ${ }^{38}$

Dua kehendak tersebut dapat dipahami karena dalam pembahasan RUU biaya yang dikeluarkan tidak sedikit, disamping kenyataan bahwa anggaran penyusunan RUU di DPR terus meningkat setiap tahun. ${ }^{39}$ Artinya, apabila proses pembentukan UU harus kembali diulang

\footnotetext{
33 Harry Alexander, Panduan Perancangan Undang-Undang Di Indonesia (Jakarta: XSYS Solusindo, 2004), 120.

34 Imam Anshori Saleh, Membenahi Hukum Dari Proklamasi Ke Reformasi: Urgensi Prolegnas Dalam Pembangunan Hukum Nasional(Jakarta: Konstitusi Press, 2009), 98.

35 Dapat diakses pada tautan berikut: http://www.dpr.go.id/dokakd/dokumen/RJI-20191028022123-8433.pdf

${ }^{36}$ Badan Legislasi DPR-RI, Naskah Akademik... 47.

${ }^{37}$ Ibid, 3.

${ }^{38} \mathrm{lbid}, 49$.

${ }^{39}$ Mira Fajriyah, "Refraksi Yuridis Penetapan Program Legislasi Nasional Di DPR RI," Jurnal Konstitusi Vol. 13, No. I (Maret 2016): 50.
} 
dari awal pada periode berikutnya, akan terjadi pemborosan yang luar biasa.

Pertanyaannya adalah apakah desain carry over pada Pasal 71A UU P3 Perubahan sejalan dengan kehendak tadi? Terkait dengan hal ini, menurut Risdiana Izzaty, carry over merupakan jawaban untuk menghindari inefisiensi APBN yang terjadi akibat pembentukan UU yang tidak dilakukan secara berkelanjutan, karena penghentian proses pembahasannya dihentikan akibat habisnya periode masa jabatan DPR. ${ }^{40}$ Carry over dinilai penting untuk mencapai efisiensi APBN karena dengan adanya carry over, anggaran yang telah digunakan untuk pembahasan pada periode sebelumnya tidak menjadi sia-sia. ${ }^{41}$ Selain itu, carry over juga dinilai memberikan kepastian hukum karena melalui carry over pembahasan RUU tidak perlu terkatung-katung hingga periode-periode selanjutnya. ${ }^{42}$ Pendapat ini nampak memberikan kesan bahwa carry over sejalan dengan kehendak otentik yang terdapat dalam naskah akademis sebagaimana dikemukakan sebelumnya.

Kendati demikian, pendapat Risdiana tersebut bersandar pada sebatas kemungkinan ${ }^{43}$ (yang berarti mungkin ya atau mungkin tidak) serta dilepaskan dari variabel politik. ${ }^{44} \mathrm{Hal}$ ini tidak tepat baik secara konsep maupun praktik. Tidak tepat secara konsep karena hukum (khususnya produk legislasi) ${ }^{45}$ merupakan produk politik ${ }^{46}$

\footnotetext{
40 Risdiana Izzaty, "Urgensi Ketentuan Carry-Over dalam Pembentukan Undang-Undang di Indonesia," Jurnal HAMVol. I I. No. I (April 2020), 88.

${ }^{41} \mathrm{Ibid}, 94$.

$42 \mathrm{lbid}, 87$.

${ }^{43} \mathrm{lbid}, 88$.

${ }^{44}$ lbid.

45 Susi Dwi Harijanti, "Penguatan Demokrasi Konstitusional: Relasi Konstitusi Dan Politik," dalam Interaksi Konstitusi Dan Politik: Kontekstualisasi Pemikiran Sri Soemantri, Ed. Susi Dwi Harijanti, dkk (Bandung: PSKN FH Unpad, 20I6), xvii.

${ }^{46}$ Moh. Mahfud MD, Politik Hukum Di Indonesia Edisi Revisi (Jakarta: Rajawali Pers, 2009), 7.
} 
dan politiklah yang menentukan suatu proses hukum. ${ }^{47}$ Dikatakan tidak tepat juga secara praktik karena kekuasaan membentuk UU ada pada badan perwakilan rakyat ${ }^{48}$ yang merupakan lembaga politik. Bahkan pada tulisan yang sama, dikatakan oleh Risdiana sendiri bahwa politik dalam pembentukan UU adalah suatu politico-legal document, pembentukan UU sangat bergantung pada proses politik yang dinamis dan tidak mudah diprediksi (unpredictable). ${ }^{49}$

Dalam konteks carry over sebagai sebuah kemungkinan, maka politiklah yang akan menentukan selanjutnya apakah kemungkinan itu cenderung menjadi "ya" atau menjadi "tidak". Pada momen inilah desain carry over yang didasarkan pada kesepakatan, perlu dilihat sebagai mekanisme politik yang menentukan kemungkinan tersebut. Hal itu berarti, tercapainya penghematan dan efektifitas anggaran serta kepastian hukum yang menjadi kehendak dalam proses pembentukan UU yang berkelanjutan melalui carry over tersebut sama sekali tidak pasti. Dengan kata lain, desain carry over pada Pasal 71A UU P3 Perubahan belum sungguh-sungguh didesain untuk menjamin terwujudnya proses pembentukan UU yang berjalan dengan hemat dan efektif serta memberikan kepastian diundangkannya suatu RUU yang tengah dibahas. Desain kebijakan carry over tidak sejalan dengan gagasan pembentukan UU yang berkelanjutan itu sendiri. Andai sebaliknya, desain carry over semestinya tidak berhenti pada "kesepakatan" yang sebatas kriteria politis, melainkan juga turut memberikan kriteria/batasan pasti yang menjamin pembahasan suatu RUU dilanjutkan pada periode berikutnya.

\footnotetext{
47 Daniel S. Lev, Hukum dan Politik di Indonesia Kesinambungan dan Perubahan, terj. Nirwono dan AE Priyono (Jakarta: LP3ES, 1990), xii.

${ }^{48}$ Bagir Manan, DPR, DPD dan MPR dalam UUD 1945 Baru (Yogyakarta: FH-UII Press, 2005), 22.

${ }^{49}$ Risdiana Izzaty, Urgensi Ketentuan..., 89
} 


\section{Berkelanjutan vs Risiko Hak Suara Wakil Rakyat yang} Terabaikan

Disamping kesepakatan, Pasal 71A UU P3 Perubahan menetapkan bahwa untuk melakukan carry over, pembahasan atas RUU yang hendak di carry over itu disyaratkan telah memasuki pembahasan DIM pada periode DPR sebelumnya. Pembahasan DIM dalam pembahasan suatu RUU dilakukan setelah kegiatan pengantar musyawarah selesai dan merupakan salah satu kegiatan yang masih berada pada pembicaraan tingkat I.50 Setelah melewati pembahasan DIM, pembahasan suatu RUU pada pembicaraan tingkat pertama akan dilanjutkan dengan penyampaian pendapat mini. Penyampaian pendapat mini disampaikan pada akhir pembicaraan tingkat I oleh Fraksi, DPD jika RUU berkaitan dengan kewenangan DPD, dan Presiden. ${ }^{51}$ Setelah melewati pembicaraan tingkat I, pembahasan RUU masuk pada pembicaraan tingkat II yang terdiri dari tiga kegiatan yakni: 52

1. Penyampaian laporan yang berisi proses, pendapat mini fraksi, pendapat mini DPD, dan hasil pembicaraan tingkat I;

2. Pernyataan persetujuan atau penolakan dari tiap-tiap fraksi dan anggota secara lisan yang diminta oleh pimpinan rapat paripurna; dan

3. Penyampaian pendapat akhir Presiden yang dilakukan oleh menteri yang ditugasi.

Lantas apakah kalimat "telah memasuki pembahasan DIM" dalam desain carry over itu bermakna "setidaknya telah memasuki pembahasan DIM"? Jika demikian maka carry over dapat dilakukan terhadap suatu RUU yang pada periode

50 Pasal 68 ayat (I), UU Nomor 12 Tahun 201 I

${ }^{51}$ Pasal 68 ayat (4), UU Nomor 12 Tahun 2011

52 Pasal 69 ayat (I), UU Nomor 12 Tahun 201 I 
sebelumnya, pembahasanya telah lewat dari pembahasan DIM, misalnya telah berada pada pembicaraan tingkat II. Atau apakah kalimat "telah memasuki pembahasan DIM" itu bermakna bahwa pembahasan pada periode berikutnya "akan dimulai kembali dari pembahasan DIM"?. Terkait dengan persoalan itu, apabila mengingat kepada semangat UU P3 Perubahan adalah pembentukan UU yang berkelanjutan, maka pemaknaan yang pertamalah yang relevan karena dengan pemaknaan tersebut pembahasan suatu RUU pada DPR periode berikutnya tidak perlu mengulangi tahap pembahasan yang telah diselesaikan oleh DPR periode sebelumnya. Selain sejalan dengan maksud penghematan dan efektifikasi anggaran serta maksud untuk mempercepat penyelesaian suatu RUU, hal itu juga dicerminkan dengan ketiadaan ketentuan untuk mengulang kembali suatu tahapan pembahasan yang telah dilakukan oleh DPR periode sebelumnya.

Penggunaan pemaknaan pertama sebagaimana dikemukakan di atas, kendati sejalan dengan semangat pembentukan UU yang berkelanjutan, namun membuka pintu munculnya persoalan baru. Ketika suatu RUU yang pada periode DPR sebelumnya telah memasuki pembicaraan tahap II serta merta dilanjutkan pembahasannya oleh DPR periode selanjutnya, lalu bagaimana apabila dalam komposisi DPR periode berikutnya itu terdapat partai politik baru yang belum ikut serta dalam pembahasan di tingkat I atas RUU tersebut?

Pada titik ini terlihat bahwa desain kebijakan carry over berisiko mengabaikan hak suara wakil rakyat dari partai politik yang mungkin baru masuk pada periode berikutnya untuk ikut serta dalam pembahasan tingkat I. Padahal penggantian jabatan wakil rakyat (yang di DPR diisi oleh anggota parpol), merupakan mekanisme pembaruan guna menangkap aspirasi, kebutuhan dan kehendak politik masyarakat yang berganti dari waktu ke 
waktu. Pengabaian terhadap hak suara wakil rakyat berarti pengabaian terhadap hak rakyat yang diwakilinya.

Berbeda hal apabila kalimat "telah memasuki pembahasan DIM" itu bermakna bahwa pembahasan pada periode berikutnya "akan dimulai kembali dari pembahasan DIM". Pada satu sisi hak suara wakil rakyat dijamin, namun pada sisi yang lain kehendak penghematan dan efektifikasi anggaran serta percepatan penyelesaian suatu RUU patut dipertanyakan, "sebelah mana letak berkelanjutannya?".

\section{Kebijakan yang "Menumpang"}

Pasal 71A UU P3 Perubahan mengatur bahwa suatu RUU yang hendak di-carry over "dapat dimasukkan kembali ke dalam daftar Prolegnas jangka menengah dan/atau Prolegnas prioritas tahunan". Apakah kata "dapat" bermakna bahwa suatu RUU yang pembahasannya hendak di-carry over itu dapat dilanjutkan pembahasannya tanpa dimasukkan kembali ke dalam daftar Prolegnas? Pemaknaan tersebut tidak tepat karena RUU yang pembahasannya dilanjutkan, ditetapkan terlebih dahulu dalam Prolegnas prioritas tahunan. ${ }^{33}$ Artinya untuk dapat dilanjutkan pembahasannya, RUU carry over dimasukkan terlebih dahulu ke dalam Prolegnas prioritas tahunan. Hal ini diperkuat dengan praktik pertama kali yang dilakukan oleh DPR periode 2020-2024 yang memasukkan RUU carry over ke dalam daftar Prolegnas prioritas tahun 2020.54

Menempatkan carry over ke dalam mekanisme Prolegnas dapat dipahami karena Prolegnas ditetapkan sebagai instrumen perencanaan dalam program

\footnotetext{
53 Pasal I 10 ayat (3) Peraturan DPR Nomor 2 Tahun 2020 tentang Pembentukan Undang-Undang

${ }^{54}$ Sebagaimana disampaikan dalam bahan yang dibagikan dalam kegiatan kunjungan kerja Badan Legislasi DPR RI ke Provinsi Jawa Barat dalam rangka sosialisasi prolegnas RUU tahun 2020-2024 dan prolegnas RUU prioritas tahun 2020 di Auditorium Mochtar Kusumaatmadja Unpad Kampus Dipatiukur pada 30 Januari 2020
} 
pembentukan undang-undang. ${ }^{55}$ Dari segi politik hukum, Prolegnas merupakan pemetaan atau potret rencana tentang hukum-hukum apa yang akan dibuat dalam periode tertentu. ${ }^{56}$ Prolegnas dinyatakan sebagai skala prioritas dalam program pembentukan UU ${ }^{57}$ yang memuat judul RUU, materi yang diatur, dan keterkaitannya dengan peraturan-perundang-undangan lainnya. ${ }^{58}$ Namun demikian, walau dinyatakan sebagai skala prioritas, pada nyatanya tidak ada jaminan proses pembahasan RUU dilakukan sesuai urutan atau rencana yang ditetapkan. ${ }^{59}$ Ketika suatu RUU masuk ke dalam daftar Prolegnas, sesungguhnya RUU itu baru masuk ke dalam wishing list pembentukan UU. Wishing list dalam artian bukan waiting list ${ }^{60}$ sehingga tidak ada jaminan RUU yang mendapatkan nomor urut 1 (satu) dalam daftar Prolegnas baik tahunan maupun jangka menengah akan diselesaikan lebih dahulu dibandingkan nomor urut berikutnya dan berikutnya. Pada titik inilah, status carry over tidak membuat suatu RUU mendapatkan prioritas diantara RUU Prolegnas prioritas yang lain untuk diselesaikan terlebih dahulu.

Carry over didesain sebagai kebijakan yang menumpang penuh pada mekanisme Prolegnas dan tidak diberikan otoritas apapun untuk menjamin proses pembentukan UU agar berlangsung secara berkelanjutan. Status carry over yang disandang oleh suatu RUU tidak

\footnotetext{
${ }^{55}$ Pasal I angka 9, UU Nomor 12 Tahun 20 I I

56 Moh. Mahfud MD, Membangun Politik..., 34

${ }^{57}$ Pasal 17, UU Nomor 12 Tahun 2011

58 Pasal 19, UU Nomor 12 Tahun 20 I I

${ }^{59}$ Andi Irman Putra, Penulisan Kerangka Ilmiah Tentang Peran Prolegnas dalam Perencanaan Pembentukan Hukum Nasional Berdasarkan UUD 1945 (Pasca Amandemen) (Jakarta: BPHN, 2008), 5.

https://www.bphn.go.id/data/documents/peran_prolegnas_dalam_perencanaan_pembentukan_h ukum_nasional.pdf

60 Merujuk Kamus Merriam Webster, "wish list is a list of desired but often realistically unobtainable items" (daftar hal yang diinginkan namun secara realistis seringkali tidak dapat diperoleh). Sementara itu, "waiting list is a list of those waiting" (daftar sesuatu hal yang menunggu untuk diselesaikan (dilayani satu per satu, -pen)) https://www.merriam-webster.com/, diakses pada I3 Mei 2020.
} 
berarti apapun ketika RUU tersebut dimasukkan ke dalam Prolegnas prioritas tahunan pada DPR periode berikutnya. Dengan masuk ke dalam Prolegnas prioritas tahunan, RUU carry over hanya diberikan "harapan" bukan "jaminan" pembahasan yang berkelanjutan. Sama halnya dengan RUU lain yang masuk ke dalam Prolegnas prioritas, RUU dengan status carry over dapat dikesampingkan pembahasannya bahkan sewaktu-waktu dapat dikeluarkan dari daftar RUU prioritas tahun itu. Pada titik inilah semangat pembentukan UU yang berkelanjutan menjadi semu dengan desain carry over yang ada. Bersamaan dengan itu, penghematan dan efektifikasi anggaran serta percepatan penyelesaian suatu RUU menjadi semu pula.

\section{Belum Sejalan dengan Desain Masa Jabatan Pembentuk} UU

Prolegnas adalah salah satu upaya pemagaran ${ }^{61}$ hukum. ${ }^{62}$ Sebagaimana dikemukakan sebelumnya, Prolegnas merupakan pemetaan atau potret rencana tentang hukum-hukum apa yang akan dibuat dalam periode tertentu. ${ }^{63}$ Berdasarkan periodisasi, Prolegnas dibagi menjadi dua macam yakni: 1) Prolegnas jangka menengah, dan 2) Prolegnas prioritas tahunan. ${ }^{64}$ Prolegnas jangka menengah disusun dan ditetapkan pada awal masa keanggotaan DPR ${ }^{65}$ yang merupakan daftar RUU untuk jangka waktu 5 (lima) tahun dalam 1 (satu) masa keanggotaan DPR.66 Sementara itu, Prolegnas prioritas

\footnotetext{
61 Pemagaran dalam arti memberikan batasan/menjaga rencana tentang hukum-hukum apa yang akan dibuat dalam periode tertentu.

62 Moh. Mahfud MD, Membangun Politik..., 16.

63 Ibid, 34.

${ }^{64}$ Pasal 20 ayat (2), UU Nomor 12 Tahun 2011.

65 Pasal 20 ayat (3), UU Nomor 12 Tahun 2011.

${ }^{66}$ Pasal I angka 2, Peraturan DPR No. 2 Tahun 2019 tentang Tata Cara Penyusunan Program Legislasi Nasional.
} 
tahunan merupakan pelaksanaan Prolegnas jangka menengah yang dilaksanakan setiap tahun. ${ }^{67}$ Dengan demikian, cukup jelas untuk dipahami bahwa Prolegnas dirancang mengikuti periode masa jabatan DPR sebagai lembaga yang berkuasa dalam pembentukan UU, yakni dirancang lima tahunan. Disamping masa jabatan DPR, masa jabatan Presiden dan DPD sebagai lembaga yang juga berwenang dalam pembentukan UU berlangsung dalam periode yang sama yakni lima tahunan. ${ }^{68}$ Dengan kata lain, pembentukan UU disesuaikan dengan desain kelembagaan pembentuk UU, khususnya terkait masa jabatan pada lembaga pembentuk UU. Hal ini logis karena ketentuan masa jabatan lembaga-lembaga negara pembentuk UU merupakan ketentuan yang langsung diatur dalam UUD NRI 1945.

Dalam tinjauan politik hukum, Imam Syaukani dan A. Ahsin Thohari berpandangan, bahwa rumusan politik hukum dapat ditemukan dalam konstitusi (UUD NRI 1945) ${ }^{69}$ dan UU yang mengatur lebih lanjut ketentuan UUD NRI 1945.70 Sementara itu Bagir Manan mengatakan, politik hukum ada yang bersifat tetap (permanen) dan ada yang sementara/temporer (dapat berubah). ${ }^{71}$ Politik hukum yang permanen merupakan sikap hukum yang akan selalu menjadi dasar kebijaksanaan pembentukan dan penegakan hukum. Sedangkan politik hukum temporer ditetapkan dari waktu ke waktu sesuai kebutuhan. Dengan menggabungkan pendekatan dari dua pandangan tersebut, dapat dipahami bahwa politik hukum tetap dan politik hukum sementara dalam pembentukan UU yang

\footnotetext{
${ }^{67}$ Pasal I angka 3, Peraturan DPR No. 2 Tahun 2019 tentang Tata Cara Penyusunan Program Legislasi Nasional.

68 Lihat ketentuan Pasal 7 UUD NRI 1945 (untuk masa jabatan Presiden) dan Pasal 22E ayat (I) dan (2) (untuk masa jabatan DPD)

${ }^{69}$ Imam Syaukani dan A. Ahsin Thohari, Dasar-Dasar..., 88.

$70 \mathrm{lbid}, \mathrm{I} \mid \mathrm{l}$.

${ }^{71}$ Bagir Manan, Politik Perundang-Undangan..., 2-3.
} 
berkelanjutan secara berturut-turut terdapat pada UUD NRI 1945 dan UU P3 Perubahan.

Berkaitan dengan politik hukum permanen dalam pembentukan UU, dapat dikatakan bahwa salah satunya adalah masa jabatan lembaga pembentuk UU dirancang dengan siklus 5 (lima) tahunan sebagaimana dikemukakan sebelumnya. Tidak seperti di Amerika Serikat dimana Kongres sebagai pembentuk UU memiliki sistem pergantian bertahap dan periode jabatan yang tidak sama (staggered system) $)^{72}$, di Indonesia DPR, DPD dan juga Presiden memulai dan mengakhiri masa jabatannya secara bersamaan sesuai siklus 5 (lima) tahunan. Ini merupakan sikap hukum yang berpengaruh terhadap dasar kebijakan pembentukan UU di Indonesia, bahwa periode masa jabatan dikehendaki sebagai patokan dan tolak ukur kinerja legislasi, sehingga dapat dipahami bahwa dalam kerangka inilah Prolegnas dirancang sebagai "pemagaran" aktifitas legislasi.

Menurut Mahfud MD, Prolegnas merupakan contoh politik hukum itu sendiri. ${ }^{73}$ Pendapat ini dapat dipahami selain karena Prolegnas secara konsep merupakan potret rencana hukum sekaligus pedoman mekanisme pembentukan hukum nasional, Prolegnas juga merupakan bagian dari UU yang didelegasikan langsung pembentukannya oleh UUD NRI 1945, yang menurut Imam Syaukani dan A. Ahsin Thohari juga mengandung rumusan politik hukum. Dengan pendekatan Bagir Manan sebagaimana dikemukakan sebelumnya, Prolegnas dapat dipahami sebagai politik hukum temporer dalam pembentukan UU di Indonesia. Disebut temporer karena

\footnotetext{
${ }^{72}$ A. Ahsin Thohari, "Kontinuitas Politik Legislasi," dalam https://nasional.sindonews.com/berita//439198// 8/kontinuitas-politik-legislasi. diakses pada 16 Mei 2020.

73 Moh. Mahfud MD, Membangun Politik..., 5.
} 
Prolegnas didesain melalui UU yang dapat diubah dari waktu ke waktu sesuai kebutuhan. Secara prosedural, mengubah ketentuan yang diatur dalam UU tentu lebih mudah dibandingkan mengubah ketentuan yang diatur dalamUUD NRI 1945. Mutatis mutandis dengan itu, mengubah desain Prolegnas dan desain carry over tentu lebih mudah dibandingkan mengubah desain masa jabatan lembaga-lembaga pembentuk UU.

Dengan mengingat bahwa carry over merupakan kebijakan yang menumpang pada Prolegnas dan mengubah desain Prolegnas lebih mudah dibandingkan mengubah desain masa jabatan lembaga-lembaga pembentuk UU, maka gambaran konstruksi yang tepat adalah desain carry over dibangun di atas desain Prolegnas yang dibangun di atas desain masa jabatan lembaga pembentuk UU. Juga dengan mengingat bahwa desain Prolegnas sejalan dengan desain masa jabatan lembaga pembentuk UU yang menghendaki periodisasi sebagai politik hukum dalam menilai kinerja legislasi, maka seyogyanya desain carry over mesti disesuaikan dengan desain politik periodisasi kinerja legislasi tersebut.

Penyesuaian desain carry over dengan politik periodisasi kinerja legislasi perlu dilakukan karena desain carry over yang terdapat dalam rumusan Pasal 71A UU P3 Perubahan justru memberikan akses yang less control untuk "melompati" pagar Prolegnas yang telah disesuaikan dengan politik hukum pembentukan UU yang digariskan oleh UUD NRI 1945, khususnya berkaitan dengan masa jabatan lembaga pembentuk UU. Dengan melompati pagar Prolegnas, carry over bukan hanya mempersulit pengukuran kinerja legislasi pada suatu periode dari aspek kuantitas, melainkan juga menggeser kepastian terciptanya UU kepada sebuah ketidakpastian, yang pada akhirnya bermuara pada pemborosan dan inefektifitas anggaran pula. Padahal carry over pada dasarnya dibuat dengan 
maksud penghematan dan efektifikasi anggaran serta menjamin selesainya pembentukan suatu UU sebagaimana telah dijelaskan sebelumnya.

Desain carry over pada UU P3 Perubahan hanya menetapkan kriteria "telah mencapai pembahasan DIM" sebagai kriteria yang pasti untuk memulai "lompatan" terhadap rintangan legislasi antarperiode yang dipagari Prolegnas, tentu saja setelah mendapatkan lampu hijau kesepakatan dari DPR, DPD dan Presiden sebagai lembaga yang berwenang dalam pembentukan UU, khususnya dalam penyusunan dan penetapan Prolegnas. Dengan kriteria itu, carry over baru didesain dengan batas bawah saja, tanpa batas atas. Batas atas dalam artian batas yang memberikan kepastian kapan RUU tersebut semestinya diselesaikan. Hal ini barangkali dapat diwakili dengan pertanyaan misalnya, apakah pembahasan suatu RUU dapat terus di-carry over hingga sepuluh, seratus, atau sekian kali pergantian masa jabatan? Jika tanpa batas, lalu kapan pembahasan suatu RUU itu semestinya selesai agar segera dapat memenuhi kebutuhan hukum yang ada? Padahal justru semestinya diadakan pembatasan waktu agar konsensus politik dapat berjalan dengan cepat, sehingga cepat pula UU dihasilkan. ${ }^{74}$ Pada titik inilah, desain carry over belum sesuai dengan arah politik hukum pembentukan UU yang menghendaki suatu RUU dapat diselesaikan dalam periode masa jabatan lembaga pembentuk UU.

Dengan dibukanya kemungkinan carry over pembahasan suatu RUU, bukan tidak mungkin dinamika yang terjadi dalam pembentukan undang-undang juga bergeser dari berorientasi "menyelesaikan UU" dalam satu periode, kepada orientasi "mencapai pembahasan DIM"

74 M. Ilham F. Putuhena, "Politik Hukum Perundang-Undangan: Mempertegas Reformasi Legislasi Yang Progresif," Jurnal Rechtvinding Vol. 2, No. 3 (Desember 2013): 393. 
semata-mata agar pembahasan RUU yang bersangkutan dapat dilanjutkan. Apabila pergeseran orientasi tersebut terjadi, lalu bagaimanakah kinerja legislasi dapat diukur baik dari aspek kuantitas maupun kualitas? Apakah baik buruknya kinerja legislasi dari aspek kuantitas dilihat dari banyaknya RUU yang berubah status menjadi UU atau dilihat dari banyaknya RUU yang mencapai pembahasan DIM? Apakah baik buruknya kinerja legislasi dari aspek kualitas dilihat dari pembahasan yang berlarut-larut dengan carry over yang tak terbatas itu? Selain itu desain carry over juga berisiko menciptakan preseden yang buruk dalam kinerja para wakil rakyat yang mungkin menjadi bermalas-malasan untuk menyelesaikan suatu RUU dengan dalih bisa dilanjutkan pembahasannya pada periode selanjutnya. Pada titik inilah, desain carry over perlu ditinjau ulang agar dapat sesuai dengan arah politik hukum yang ada.

\section{Penyesuaian yang Dibutuhkan}

Dalam konteks negara yang berdasarkan hukum, persoalan hukum yang timbul perlu dicarikan solusi agar tercapai kepastian. ${ }^{75}$ Apalagi persoalan itu terletak pada peraturan yang mengatur pembentukan hukum itu sendiri. Penyesuaian desain carry over dengan politik legislasi yang berpatokan pada periodisasi masa jabatan pembentuk UU tidak berarti menolak cita-cita pembentukan UU yang berkelanjutan dalam UU P3 Perubahan. Penyesuaian desain carry over mesti dipandang sebagai penyesuaian rancang bangun kebijakan carry over yang tepat, dari sisi sebelah mana carry over itu seharusnya dicangkok pada Prolegnas, agar mampu menjadi jembatan legislasi antarperiode tanpa mengesampingkan tolak ukur kinerja legislasi yang berbasis

75 Retno Saraswati, "Problematika Hukum Undang-Undang No.12 Tahun 20II Tentang Pembentukan Peraturan Perundang-Undangan," Yustisia Jurnal Hukum Vol. 2, No. 3 (September-Desember, 20 I3): 97. 
periode jabatan sebagaimana dikehendaki oleh UUD NRI 1945 dan UU Nomor 12 Tahun 2012. Penyesuaian ini mesti diartikan dengan menyandingkan kehendak diaturnya mekanisme carry over dengan politik hukum pembentukan UU yang dikehendaki UUD NRI 1945.

Telah diuraikan sebelumnya, pokok dari kehendak diaturnya mekanisme carry over dalam rangka memperkuat pembentukan undang-undang yang berkelanjutan yakni:

1. Guna penghematan dan efektifitas sumberdaya, waktu dan anggaran dengan maksud agar sumberdaya, waktu, dan anggaran tidak terbuang sia-sia; ${ }^{76}$. Selain itu juga agar tidak terjadi pemborosan akibat proses pembahasan yang diulang kembali dari nol ${ }^{77}$

2. Memastikan pembahasan suatu RUU berlangsung secara berkelanjutan hingga RUU bersangkutan dapat diundangkan. ${ }^{78}$

Sementara pokok dari politik hukum pembentukan UU dikaitkan dengan masa jabatan pembentuk undang-undang yang digariskan UUD NRI 1945 adalah tercapainya kepastian terbentuknya UU dengan memberikan batasan waktu yang dijalankan melalui Prolegnas. Irisan yang secara jelas bisa didapatkan adalah cita-cita pembentukan UU itu menghendaki terciptanya suatu UU yang menjadi kebutuhan. Sebab suatu pembentukan UU tidak akan mencapai tingkat efektif apabila pembahasan RUU tersebut tidak selesai dan disahkan menjadi UU.

Berkaitan dengan penghematan dan efektifitas sumberdaya, waktu dan anggaran, sejatinya dapat dicapai andai saja pembahasan suatu RUU sanggup diselesaikan dalam satu periode masa jabatan DPR. Seharusnya cita-cita memperkuat proses pembentukan UU yang berkelanjutan itu, tetap diupayakan dalam kerangka politik hukum legislasi berdasarkan periodisasi

\footnotetext{
${ }^{76}$ Badan Legislasi DPR-RI, Naskah Akademik..., 47.

77 lbid, 3.

${ }^{78}$ Ibid, 49.
} 
sebagaimana digariskan oleh UUD NRI 1945. Pembentukan UU didorong agar selesai sesuai dengan masa jabatan pembentuk UU, namun dalam kondisi-kondisi tertentu diberikan "lorong kecil" berupa carry over untuk menembus batasan periode yang ada. Artinya, carry over tidak boleh didesain sebagai "jalan tol" dalam sistem pembentukan UU. Carry over tidak boleh didesain sebagai kebijakan yang minim pembatasan melainkan mesti didesain sebagai kebijakan yang sangat terbatas. Dengan begitu, pembentuk UU tidak serta merta mudah memanfaatkan carry over sebagai permakluman atas buruknya kinerja legislasi suatu periode yang minim menggolkan UU dari aspek kuantitas, serta sebagai sebuah legitimasi mengulur-ngulur pembahasan atas nama kualitas.

Berkaitan dengan carry over merupakan kebijakan yang menumpang pada Prolegnas, maka perlu dilakukan pembenahan dalam Prolegnas itu sendiri. Misalnya yakni:

1. Pengetatan kriteria seleksi RUU sehingga hanya RUU yang memiliki urgensitas tinggi saja yang masuk ke dalam daftar Prolegnas. Hal ini berkaitan dengan kenyataan bahwa Prolegnas seringkali disusun dengan kuantitas target yang tinggi, namun capaian realisasinya rendah. ${ }^{79}$

2. Penambahan waktu dalam pembentukan Prolegnas di awal periode DPR. ${ }^{80}$

3. Mengubah bentuk hukum Prolegnas dari sebuah Keputusan DPR menjadi sebuah UU. ${ }^{81}$

4. Membangun mekanisme kerja legislasi yang efisien dan sistematis. ${ }^{82}$

\footnotetext{
${ }^{79}$ Ratnia Solihah dan Siti Witianti, "Pelaksanaan Fungsi Legislasi Dewan Perwakilan Rakyat Pasca Pemilu 20 I 4: Permasalahan Dan Upaya Mengatasinya," CosmoGov Vol. 2, No. 2 (Oktober 20 I 6): 297.

80 Fajri Nursyamsi, "Menggagas Prolegnas Berkualitas," dalam https://www.pshk.or.id/blogid/menggagas-prolegnas-berkualitas/. diakses pada 16 Mei 2020.

81 Mei Susanto, Penguatan Prolegnas..., 340-342.

82 Muh. Risnain, "Konsep Peningkatan Kuantitas dan Kualitas Program Legislasi Nasional: Rekomendasi Konseptual dan Kebijakan pada Prolegnas 2015-2019," Jurnal Rechtsvinding Vol. 4, No. 3 (Desember 20 I5): 400-40I,
} 
Carry over juga perlu didesain dengan ketentuan yang lebih mapan, ketat dan pasti dari sekedar ketentuan yang terdapat pada Pasal 71A UU P3 Perubahan saja. Perlu pula diatur mengenai:

1. RUU seperti apa yang pembahasanya boleh di-carry over. Hal ini karena pembentukan UU merupakan masalah yang kompleks dan berdimensi luas. ${ }^{83}$ Sehingga kriteria RUU seperti apa yang boleh di-carry over perlu ditentukan berkaitan dengan:

a. Pertimbangan kompleksitas materi muatan. Misalnya UU kodifikasi (KUHP, dst), UU sapu jagat (omnibus law), dan lain-lain yang memiliki materi muatan yang banyak dan kompleks.

b. Pertimbangan kompleksitas kepentingan. Misalnya UU yang melibatkan banyak lembaga negara dalam pembahasannya, UU yang berisiko menimbulkan konflik horizontal di masyarakat, dan lain-lain.

2. Ketentuan darimana pembahasan pada periode berikutnya akan dimulai, untuk menjamin hak suara anggota dari partai yang baru masuk pada periode selanjutnya.

3. Ketentuan batasan praktik carry over. Misalnya, suatu RUU dibatasi hanya boleh di-carry over sebatas satu kali saja dengan pertimbangan Presiden dapat menjabat $2 \times 5$ tahun, sehingga visi misi legislasi yang diusung tidak jauh berbeda. Hal ini juga memberikan penegasan bahwa suatu RUU harus diselesaikan maksimal dalam kurun waktu 10 tahun.

4. Ketentuan mengenai prioritasi RUU berstatus carry over dalam Prolegnas jangka menengah maupun Prolegnas prioritas tahunan sehingga dapat didahulukan pembahasannya dari RUU yang lain.

83 A.A. Oka Mahendra, "Program Legislasi Nasional Instrumen Perencanaan Pembentukan Peraturan Perundang-Undangan," Jurnal Legislasi Indonesia Vol. 2, No. I (Maret 2005): 5. 


\section{Penutup}

Berdasarkan analisis di atas, dapat disimpulkan bahwa kebijakan carry over baru dapat diwujudkan dengan efektif dalam politik hukum pembentukan undang-undang yang berkelanjutan di Indonesia sejauh didesain sebagai kebijakan yang sangat terbatas. Dengan desain yang terbatas, pembentuk UU dapat dicegah agar tidak serta merta mudah memanfaatkan carry over sebagai dalih penundaan suatu RUU. Desain kebijakan carry over yang ada saat ini perlu dievaluasi agar pembentukan UU yang berkelanjutan dapat benar-benar terwujud sesuai original intent diadakannya kebijakan carry over itu sendiri. Desain kebijakan carry over juga perlu disesuaikan dengan politik hukum permanen dan politik hukum temporer pembentukan UU di Indonesia yang memang menghendaki pembentukan UU berlangsung secara periodik. Evaluasi dan penyesuaian tersebut berkaitan dengan 5 (lima) poin persoalan yakni: pertama, rumusan yang tidak mengikat dan tidak memberikan kepastian, sehingga tidak ada jaminan pembahasan suatu RUU akan dilanjutkan pada periode berikutnya; kedua, rumusan yang tidak sejalan dengan gagasan, sehingga penghematan sumber daya serta kepastian terciptanya UU tidak dapat dicapai; ketiga, adanya risiko hak suara wakil rakyat yang terabaikan, sehingga perlu diatur ketentuan mengenai darimana pembahasan pada periode berikutnya akan dilakukan; keempat, desain yang menumpang pada Prolegnas, sehingga penerapan carry over juga perlu diikuti dengan perbaikan terhadap desain kebijakan Prolegnas; dan kelima, desain belum sesuai dengan politik periodisasi dalam kinerja legislasi yang berpotensi mempersulit pengukuran kinerja legislasi baik secara kuantitas maupun kualitas. Carry over perlu didesain sebagai kebijakan yang terbatas agar pada penerapannya tidak disalahgunakan, namun disaat yang sama tetap mampu memberikan jaminan penghematan dan efektifikasi sumberdaya serta kepastian terciptanya UU dalam rangka mewujudkan pembentukan UU yang berkelanjutan di Indonesia. 


\section{Daftar Pustaka}

Al Atok, A. Rosyid. Konsep Pembentukan Peraturan PerundangUndangan. Malang: Setara Press, 2015

Alexander, Harry. Panduan Perancangan Undang-Undang di Indonesia. Jakarta: XSYS Solusindo, 2004

Anggoro, Syahriza Alkohir. "Politik Hukum: Mencari Sejumlah Penjelasan." Jurnal Cakrawala Hukum Vol. 10, No. 1. Juni, 2019. BPHN. Tiga Dekade Prolegnas dan Peran BPHN. Jakarta: Departemen Hukum dan Hak Asasi Manusia RI, 2008

Djamali, Abdoel. Pengantar Hukum Indonesia Edisi Revisi. Jakarta: Rajawali Pers, 2014

DPR-RI, Badan Legislasi. Evaluasi Prolegnas Tahun 2010-2014. Jakarta: DPR-RI, 2014.

DPR-RI, Badan Legislasi. Naskah Akademik Rancangan UndangUndang Republik Indonesia tentang Perubahan atas UndangUndang Nomor 12 Tahun 2011 tentang Pembentukan PerundangUndangan. Jakarta: DPR-RI, 2019.

Fajriyah, Mira. "Refraksi Yuridis Penetapan Program Legislasi Nasional Di DPR RI." Jurnal Konstitusi Vol. 13, No. 1. Maret, 2016.

Harijanti, Susi Dwi. "Penguatan Demokrasi Konstitusional: Relasi Konstitusi dan Politik." dalam Interaksi Konstitusi dan Politik: Kontekstualisasi Pemikiran Sri Soemantri, Ed. Susi Dwi Harijanti, dkk. Bandung: PSKN FH Unpad, 2016

Izzati, Risdiana. "Urgensi Ketentuan Carry-Over dalam Pembentukan Undang-Undang di Indonesia." Jurnal HAM Vol.11 No. 1. April, 2020.

Kamus Merriam Webster, https://www.merriam-webster.com/

Latif, Abdul dan Ali, Hasbi. Politik Hukum. Jakarta: Sinar Grafika, 2010

Lev, Daniel S. Hukum dan Politik Di Indonesia Kesinambungan Dan Perubahan. Jakarta: LP3ES, 1990 
Mahendra, A.A. Oka. "Program Legislasi Nasional Instrumen Perencanaan Pembentukan Peraturan PerundangUndangan." Jurnal Legislasi Indonesia Vol. 2, No. 1. Maret, 2005.

Manan, Bagir. DPR, DPD dan MPR dalam UUD 1945 Baru. Yogyakarta: FH-UII Press, 2005.

-- - Politik Perundang-Undangan. Cisarua-Bogor: Penataran Dosen FH/STH PTS Se-Indonesia, 1993.

MD, Moh. Mahfud. Membangun Politik Hukum Menegakkan Konstitusi. Jakarta: Rajawali Pers, 2012.

- - . Politik Hukum di Indonesia Edisi Revisi. Jakarta: Rajawali Pers, 2009.

Mugiyati. Pengkajian Konstitusi. Jakarta: Badan Pembinaan Hukum Nasional, 2011

Nursyamsi, Fajri. "Menggagas Prolegnas Berkualitas." dalam https://www.pshk.or.id/blog-id/menggagas-prolegnasberkualitas/ (4 Februari 2015)

Peraturan DPR Nomor 2 Tahun 2019 tentang Tata Cara Penyusunan Program Legislasi Nasional.

Peraturan DPR Nomor 2 Tahun 2020 tentang Pembentukan Undang-Undang.

Putra, Andi Irman. Penulisan Kerangka Ilmiah tentang Peran Prolegnas dalam Perencanaan Pembentukan Hukum Nasional Berdasarkan UUD 1945 (Pasca Amandemen). Jakarta: BPHN, 2008

Putuhena, M. Ilham F. "Politik Hukum Perundang-Undangan: Mempertegas Reformasi Legislasi Yang Progresif." Jurnal Rechtvinding Vol. 2, No. 3. Desember, 2013

Risnain, Muh. “Konsep Peningkatan Kuantitas dan Kualitas Program Legislasi Nasional: Rekomendasi Konseptual dan Kebijakan pada Prolegnas 2015-2019." Jurnal Rechtsvinding Vol. 4, No. 3. Desember, 2015

Saleh, Imam Anshori. Membenahi Hukum dari Proklamasi ke Reformasi: Urgensi Prolegnas dalam Pembangunan Hukum Nasional. Jakarta: Konstitusi Press, 2009 
Muldan Halim P, et.al.

Saraswati, Retno. "Problematika Hukum Undang-Undang No.12 Tahun 2011 Tentang Pembentukan Peraturan PerundangUndangan." Yustisia Jurnal Hukum Vol. 2, No. 3. SeptemberDesember, 2013.

Sidharta, B. Arief. Meuwissen Tentang Pengembangan Hukum, Ilmu Hukum, Teori Hukum dan Filsafat Hukum. Bandung: Refika Aditama, 2003

Soedarto. Hukum Pidana dan Perkembangan Masyarakat Kajian Terhadap Hukum Pidana. Bandung: Sinar Baru, 1983

Solihah, Ratnia, dan Witianti, Siti. "Pelaksanaan Fungsi Legislasi Dewan Perwakilan Rakyat Pasca Pemilu 2014: Permasalahan Dan Upaya Mengatasinya." CosmoGov Vol. 2, No. 2. Oktober, 2016.

Sopiani dan Mubaroq, Zainal. "Politik Hukum Pembentukan Peraturan Perundang-Undangan Pasca Perubahan UndangUndang Nomor 12 Tahun 2011 Tentang Pembentukan Peraturan Perundang-Undangan." Jurnal Legislasi Indonesia Vol. 17, No. 2. Juni, 2020.

Susanto, Mei. "Penguatan Prolegnas Sebagai Dasar Politik Pembentukan Undang-Undang." dalam Strategi Perampingan dan Harmonisasi Regulasi Pusat Dan Daerah. Jakarta: Badan Pengkajian MPR-RI, 2017.

Syaukani, Imam dan Thohari, A. Ahsin. Dasar-Dasar Politik Hukum. Jakarta: PT Raja Grafindo Persada, 2012.

Taib, Mukhlis. Dinamika Perundang-Undangan di Indonesia. Bandung: Refika Aditama, 2017

Thohari, A. Ahsin. "Kontinuitas Politik Legislasi." dalam https://nasional.sindonews.com/berita/1439198/18/kontinuit as-politik-legislasi (13 September 2019)

Undang-Undang Dasar Negara Republik Indonesia Tahun 1945.

Undang-Undang Republik Indonesia Nomor 12 Tahun 2011 tentang Pembentukan Peraturan Perundang-Undangan. 
Undang-Undang Republik Indonesia Nomor 15 Tahun 2019 tentang Perubahan Undang-Undang Nomor 12 Tahun 2011 tentang Pembentukan Peraturan Perundang-Undangan.

Wiratraman, Herlambang P. "Penelitian Sosio-Legal dan Konsekuensi Metodologisnya." Surabaya: Center of Human Right Law Studies (HRLS), Fakultas Hukum Universitas Airlangga, t.t.

Yuliandri. Asas-Asas Pembentukan Peraturan Perundang-Undangan yang Baik: Gagasan Pembentukan Undang-Undang Berkelanjutan. Jakarta: PT Raja Grafindo Persada, 2009 